Jurnal Ecobisma Vol 5 No. 2 Juni 2018

\title{
PENGARUH KESELAMATAN DAN KESEHATAN KERJA (K3) TERHADAP PRESTASI KERJA KARYAWAN PADA PT. PERTAMINA (PERSERO) MEDAN
}

\author{
Aulia Indra
}

Auliaindra91@gmail.com

Dosen Sekolah Tinggi Ilmu Ekonomi (STIE) Labuhan Batu, Indonesia

\section{Abstract}

Occupational Health and Safety (K3) is a system of programs designed for both workers and employers in an effort to prevent the occurrence of occupational accidents and diseases caused by working relations in the work environment by identifying the things that potentially cause workplace accidents and anticipatory action in the event of such a thing. The resulting impact of this workplace accidents can be bad, such as the loss of lives, disability, damage to production, which is ultimately detrimental to all parties. In Indonesia, every company has to follow the program of the Occupational Health and Safety (K3), but can be seen in workplace accidents are still common. The purpose of this research was to determine the effect of occupational safety and health (K3) on employee performance in PT. Pertamina (Persero) Medan. Digunakana research method is simple linear regression.

The estimation deskriptif showed that is company an very important for health and safety (K3) on employee company and the health and safety (K3) positif and significant effect on employee performance in PT. Pertamina (Persero) Medan.

Keywords: Health and Safety (K3), Employee Performance

\section{PENDAHULUAN}

\section{Latar Belakang Penelitian}

Sumber daya manusia adalah salah satu aset utama yang berfungsi sebagai penggerak operasional perusahaan. Setiap perusahaan menyadari bahwa sumber daya manusia yang profesional, terpercaya, berkompeten dan tekun adalah kunci bagi perusahaan dalam pencapaian tujuannya. Simamora (2006:76) berpendapat bahwa kunci kesuksesan sebuah perusahaan bukan hanya terletak pada keunggulan teknologi dan ketersediaan dana saja, akan tetapi faktor sumber daya manusia atau karyawan merupakan salah satu faktor yang terpenting pula. Karyawan dengan tingkat prestasi kerja yang maksimal sangat dibutuhkan untuk mencapai tujuan perusahaan dan prestasi kerja karyawan menjadi salah satu sorotan utama ketika sebuah perusahaan mengalami kemunduran. Untuk mencegah terjadinya kemunduran dalam suatu perusahaan, maka segala daya upaya dilakukan oleh perusahaan antara lain salah satunya adalah dengan meningkaktan keselamatan dan kesehatan kerja (K3).

Keselamatan dan Kesehatan Kerja (K3) adalah suatu sistem program yang dibuat bagi pekerja maupun pengusaha sebagai upaya pencegahan timbulnya kecelakaan kerja dan penyakit akibat hubungan kerja dalam lingkungan kerja 


\section{Jurnal Ecobisma Vol 5 No. 2 Juni 2018}

dengan cara mengenali hal- hal yang berpotensi menimbulkan kecelakaan kerja serta tindakan antisipatif bila terjadi hal demikian. Dampak yang dihasilkan dari kecelakaan kerja ini pun dapat berakibat buruk, seperti adanya korban jiwa, cacat, kerusakan hasil produksi, yang pada akhirnya merugikan semua pihak. Di Indonesia, setiap perusahaan telah mengikuti program mengenai Keselamatan dan Kesehatan Kerja (K3), akan tetapi dapat dilihat kecelakaan kerja masih kerap terjadi. Berbagai tuntutan tentang masalah keselamatan dan kesehatan kerja ini, menyadarkan perusahaaan harus memberi perhatian lebih dalam memenuhi tanggung jawabnya untuk memberikan perlindungan pada karyawan. Berkaitan dengan bahaya yang akan timbul dalam bekerja, kedisiplinan dalam bekerja menjadi salah satu sorotan ketika keteledoran yang terjadi dapat mempengaruhi keselamatan kerja karyawan.

Secara sadar ataupun tidak sadar, kita menghadapi dan menjalani dua macam situasi yaitu situasi masalah (problem situation) dan situasi pilihan (choice situation) yang disebut juga dengan situasi konflik. Dalam situasi masalah seseorang menghadapi berbagai macam rintangan dalam upaya mencapai tujuan yang diinginkan. Proses dan besarnya upaya seseorang untuk mengatasi rintangan-rintangan agar dapat mencapai tujuan dapat digambarkan dengan motivasi untuk dapat melalui rintangan-rintangan yang ada. Sedangkan situasi pilihan, seseorang menghadapi beberapa alternatif keputusan ataupun tindakan yang mengarah pada tujuan tertentu, mengarah pada timbulnya akibat-akibat tertentu. Tujuan atau akibat ini dapat memiliki aspek baik aspek positif maupun asepek negatif. Dalam konflik, seseorang akan memiliki kesulitan untuk memilih jika dalam pemilihan itu mengandung aspek positif atau negatif yang sama nilainya. Motivasi memiliki aspek kebutuhan, tujuan, kegiatan/aktivitas dan tenaga yang digunakan untuk melaksanakan kegiatan. Banyak sedikitnya tenaga yang digunakan tergantung dari pentingnya tujuan bagi seseorang atau individu dalam mencapai tujuan.

Tetapi dalam pengamatan yang peneliti lakukan di PT. Pertamina (Persero) Medan, masih ada beberapa karyawan yang tidak mengindahkan prosedur program Keselamatan dan Kesehatan Kerja (K3) dalam perusahaan. Selain dari masalah tentang kedisiplinan dalam penerapan program Keselamatan dan Kesehatan Kerja (K3) yang telah diuraikan sebelumnya, masih ada beberapa masalah mengenai ketidak disiplin dalam bekerja.

Tabel 1.

Jumlah Kecelakaan Kerja Pada PT. Pertamina (Persero) Medan Tahun $2012-2015$

\begin{tabular}{|c|c|c|c|c|}
\hline Nomor & Tahun & $\begin{array}{c}\text { Jumlah Tenaga } \\
\text { Kerja }\end{array}$ & $\begin{array}{c}\text { Yang Mengalami } \\
\text { Kecelakaan }\end{array}$ & Persentase \\
\hline 1 & 2012 & 97 & 4 & 3,88 \\
\hline 2 & 2013 & 91 & 3 & 2,73 \\
\hline 3 & 2014 & 96 & 4 & 3,84 \\
\hline 4 & 2015 & 93 & 2 & 1,86 \\
\hline
\end{tabular}

Sumber : PT. Pertamina (Persero) Medan, 2016. 


\section{Jurnal Ecobisma Vol 5 No. 2 Juni 2018}

Prestasi kerja merupakan indikator utama bagi kemajuan sebuah perusahaan, sehingga peningkatan produktivitas kerja karyawan pada semua bagian sistem merupakan suatu cara untuk meningkatkan kinerja karyawan. Faktor keamanan dan perlindungan dalam bekerja menjadi salah satu faktor prestasi kerja karyawan. Ketika karyawan memiliki rasa aman dan nyaman karena dirinya merasa mendapatkan perlindungan yang baik dari perusahaan, maka karyawan tersebut juga akan bekerja dengan perasaan yang tenang dan akan bekerja secara baik. Diharapkan karyawan perusahaan yang seperti ini akan memiliki prestasi kerja yang maksimal. Salah satu upaya dalam menerapkan perlindungan bagi karyawan adalah dengan melaksanakan program Keselamatan dan Kesehatan Kerja (K3).

Tentunya pembagian ini juga akan bermuara bagi kesejahteraan kehidupan karyawan juga. Berdasarkan uraian yang telah dikemukakan diatas, peneliti merasa tertarik untuk membuat suatu kajian yang lebih mendalam mengenai masalah tersebut yang berbentuk karya ilmiah yang penulis beri judul : "Pengaruh Keselamatan dan Kesehatan Kerja Terhadap Prestasi kerja Karyawan PT. Pertamina (Persero) Medan”.

\section{KAJIAN PUSTAKA}

\section{Penelitian Terdahulu}

Penelitian yang relevan dengan penulis teliti adalah :

1. Tsenawatme, Aleks (2012), dengan judul penelitiannya adalah : "Pengaruh Keselamatan Dan Kesehatan Kerja Terhadap Kinerja Karyawan (Studi Pada Departemen Social Outreach \& Local Development (SLD) dan Community Relations (CR) PT.Freeport Indonesia)". Hasil perhitungan antara keselamatan dan kesehatan kerja terhadap kinerja karyawan dengan analisis regresi menunjukkan bahwa keselamatan dan kesehatan kerja berpengaruh pada kinerja karywan pada Departemen Social Outreach \& Local Development/Community Relation (SLD/CR) PT.Freeport Indonesia.

2. Hasanah, Iswatun (2014), dengan judul penelitiannya adalah "Pengaruh Keselamatan dan Kesehatan Kerja terhadap Kinerja Karyawan CV Manunggal Jaya di Boyolali”. Hasil penelitiannya menunjukkan bahwa keselamatan dan kesehatan kerja berpengaruh signifikan dan positif terhadap kinerja karyawan CV. Manunggal Jaya Boyolali. Berdasarkan hasil pengujian empiris variabel program keselamatan dan kesehatan kerja memiliki nilai koefisien sebesar 0.725 dengan nilai t hitung 4.923 serta nilai signifikansi 0.001 .

3. Paramita, Catarina Cori Pradnya (2012), dengan judul penelitiannya adalah : "Pengaruh Keselamatan Dan Kesehatan Kerja Terhadap Prestasi Kerja Karyawan Pada PT. PLN (Persero) APJ Semarang". Berdasarkan hasil penelitian, maka dapat disimpulkan bahwa keselamatan kerja dan kesejahteraan (K3) berpengaruh signifikan terhadap kinerja karyawan yang dimediasi oleh variabel motivasi kerja.

\section{Kerangka Teoritis \\ Pengertian Prestasi Kerja}

Istilah prestasi kerja atau kinerja merupakan pengalih bahasaan dari kata performance. Menurut Ruky (2002 : 19) definisi performance adalah catatan tentang hasil-hasil yang diperoleh dari fungsi-fungsi pekerjaan tertentu atau 


\section{Jurnal Ecobisma Vol 5 No. 2 Juni 2018}

kegiatan tertentu selama kurun waktu tertentu. Prestasi menekankan pengertian sebagai hasil atau apa yang keluar (outcomes) dari sebuah pekerjaan dan kontribusi mereka pada organisasi.

Menurut Hasibuan (2005: 94) prestasi kerja adalah hasil kerja yang dicapai seseorang dalam melaksanakan tugas tugas yang dibebankan kepadanya yang di dasarkan atas kecakapan, pengalaman, dan kesungguhan serta waktu. Prestasi kerja merupakan gabungan dari tiga faktor penting yaitu kemampuan dan minat seorang pekerja,kemampuan dan penerima atas penjelasan delegasi tugas, serta peran dan tingkat motivasi seorang pekerja. Semakin tinggi ketiga faktor di atas, semakin besarlah prestasi kerja karyawan bersangkutan.

\section{Ruang Lingkup Penilaian Prestasi}

Ruang lingkup penilaian prestasi dicakup dalam what, why, where, when, who, dan how Bering disingkat dengan $\mathrm{SW}+1 \mathrm{H}$

a. What (apa) yang dinilai

Yang dinilai perilaku dan prestasi kerja karyawan seperti kesatuan, kejujuran, kerjasama, kepemimpinan, loyalitas, pekerjaan saat sekarang potensi akan datang, sifat dan hasil kerjanya

b. Why (kenapa) dinilai

1) Untuk menambah tingkat kepuasaan para karyawan dengan memberikan pengakuan terhadap hasil kerjanya.

2) Untuk membantu kemungkinan pengembangan personel bersangkutan

3) Untuk mengukur potensi kerja

4) Untuk mengukur prestasi kerja para karyawan

5) Untuk mengukur kemampuan dan kecakapan karyawan

6) Untuk mengumpulkan data guna menetapkan program kepegawaian selanjutnya

c. How (bagaimana) menilainya

Metode penilaian apa yang digunakan dan problem apa yang dihadapi oleh penilai (appraiser) dalam melakukan penilaian

\section{Tujuan Penilaian Prestasi Kerja}

Penilaian prestasi kerja karyawan berguna bagi organisasi dan harus bermanfaat bagi karyawan. Tujuan penilaian prestasi karyawan sebagai berikut :

a. Sebagai dasar dalam pengambilan keputusan yang digunakan untuk promosi, demosi, pemberhentian dan penetapan besarnya balas jasa.

b. Untuk mengukur sejauh mana karyawan bisa sukses dalam pekerjaannya.

c. Sebagai dasar untuk mengevaluasi efektivitas seluruh kegiatan didalam organisasi.

d. Sebagai dasar untuk mengevaluasi program latihan dan keefektifan jadwal kerja, metode kerja, struktur organisasi, gaya pengawasan, kondisi kerja dan peralatan kerja.

e. Sebagai indikator untuk menentukan kebutuhan akan latihan bagi karyawan yang berada didalam organisasi.

f. Sebagai alat untuk meningkatkan motivasi kerja karyawan sehingga tercapai tujuan untuk mendapatkan prestasi kerja yang baik. 


\section{Jurnal Ecobisma Vol 5 No. 2 Juni 2018}

g. Sebagai alat untuk mendorong atau membiasakan atasan untuk mengobservasi perilaku bawahan supaya diketahui minat dan kebutuhan-kebutuhan bawahannya.

h. Sebagai alat untuk bisa melihat kekurangan dimasa lampau dan meningkatkan kemampuan karyawan selanjutnya.

i. Sebagai kriteria dalam menentukan seleksi dan penempatan karyawan.

j. Sebagai dasar untuk memperbaiki dan mengembangkan uraian pekerjaan.

Meskipun penilaian prestasi kerja mempunyai banyak manfaat, namun masih banyak pimpinan yang tidak bersedia melakukan. Adapun penyebabnya (Panggabean, 2002) antara lain :

a. Pihak penilai tidak merasa memiliki, karena mereka tidak dilibatkan dalam menentukan sistem penilaian, tidak dilatih untuk dapat menggunakan sistem yang ada dan usulan terhadap sistem yang ada tidak diperhitungkan.

b. Adanya keterlibatan secara pribadi. Pimpinan enggan memberikan nilai yang buruk kepada karyawan khususnya orang yang disukai secara pribadi.

c. Penilaian yang buruk cenderung menimbulkan reaksi untuk bertahan atau bermusuhan daripada untuk mendorong meningkatkan kinerja karyawan.

d. Pimpinan maupun bawahan menyadari bahwa penilaian yang buruk akan mempengaruhi karir seseorang.

e. Dalam kenyataannya proses penilaian prestasi kerja tidak dimanfaatkan untuk menentukan kebijaksanaan dalam pemberian penghargaan.

f. Adanya keraguan dari pimpinan untuk memberikan penilaian yang buruk karena takut tidak mampu untuk memilih dan mengembangkan karyawan. Bagi karyawan, penilaian prestasi kerja dapat menimbulkan perasaan puas dalam diri mereka, karena dengan cara ini hasil kerja mereka dinilai oleh organisasi dengan sewajarnya dan kelemahan-kelemahan yang ada dalam individu karyawan dapat diketahui. Kelemahan-kelemahan tersebut harus diterima secara sadar oleh karyawan sebagai suatu kenyataan dan pada akhirnya akan menimbulkan dorongan untuk memperbaiki diri.

\section{Faktor Penilaian Prestasi Kerja}

Menurut William dalam Wungu, (2003:48) menunjuk adanya sembilan kriteria faktor penilaian prestasi kerja pegawai, yaitu :

a. Reliable, harus mengukur prestasi kerja dan hasilnya secara obyektif.

b. Content valid, secara rasional harus terkait dengan kegiatan kerja.

c. Defined spesific, meliputi segenap perilaku kerja dan hasil kerja yang dapat diidentifikasi.

d. Independent, perilaku kerja dan hasil kerja yang penting harus tercakup dalam kriteria yang komprehensif.

e. Non-overlaping, tidak ada tumpang tindih antar kriteria.

f. Comprehensive, perilaku kerja dan hasil kerja yang tidak penting harus dikeluarkan.

g. Accessible, kriteria haruslah dijabarkan dan diberi nama secara komprehensif.

h. Compatible, kriteria harus sesuai dengan tujuan dan budaya organisasi.

i. Up to date, sewaktu-waktu kriteria perlu ditinjau ulang menilik kemungkinan adanya perubahan organisasi.

Prestasi kerja dihasilkan oleh adanya 3 (tiga) hal, yaitu : 


\section{Jurnal Ecobisma Vol 5 No. 2 Juni 2018}

a. Kemampuan (ability) dalam wujudnya sebagai kapasitas untuk berprestasi (capacity to perform).

b. Kemampuan, semangat, hasrat atau motivasi dalam wujudnya sebagai kesediaan untuk berprestasi (willingness to perform).

c. Kesempatan untuk berprestasi (opportunity to perform)

Menurut Gomes (2003:142) penilaian prestasi kerja dapat dilakukan berdasarkan deskripsi perilaku yang spesifik yaitu :

a. Quantity of work, jumlah kerja yang dilakukan dalam suatu periode waktu yang ditentukan.

b. Quality of work, kualitas kerja yang dicapai berdasarkan syarat-syarat kesesuaian dan kesiapannya.

c. Job knowledge, luasnya pengetahuan mengenai pekerjaan dan ketrampilan

d. Creativeness, keaslian gagasan-gagasan yang dimunculkan dan tindakantindakan untuk menyelesaikan persoalan-persoalan yang timbul.

e. Cooperation, kesediaan untuk bekerjasama dengan orang lain.

f. Dependability, kesadaran dan dapat dipercaya dalam hal kehadiran dan penyelesaian pekerjaan.

g. Initiative, semangat untuk melaksanakan tugas-tugas baru dan dalam memperbesar tanggungjawabnya.

h. Personal qualities, menyangkut kepribadian, kepemimpinan, keramahtamahan dan integritas pribadi.

Dari beberapa kajian teoritis di atas maka diambil beberapa item kriteria yang sesuai dengan tujuan penelitian, yaitu :

1) Disiplin kerja (kehadiran) yaitu ketepatan pegawai untuk hadir ke kantor dan kemangkiran dengan ijin atau tanpa ijin atasan.

2) Kualitas kerja yaitu mutu dan ketepatan pegawai dalam melaksanakan pekerjaan yang dibebankan kepadanya.

3) Kemampuan (ketrampilan) kerja yaitu kemampuan, pengetahuan dan penguasaan pegawai atas teknis pelaksanaan tugas yang diberikan.

4) Potensi yaitu kemampuan pegawai untuk bekerja secara proaktif dan inovatif melalui gagasan baru yang dapat meningkatkan kinerjanya.

Alasan dipilihnya kriteria tersebut di atas adalah menurut pengamatan peneliti dari kajian teoritis disesuaikan dengan situasi dan kondisi lingkungan penelitian dan melihat adanya permasalahan dilapangan.

\section{Faktor-Faktor yang mempengaruhi Prestasi Kerja}

Sedangkan peran serta tenaga kerja disini adalah penggunaan sumber daya secara efektif dan efisien sehingga dapat meningkatkan prestasi kerja baik secara individu maupun kelompok. Menurut Heidjaracman (2011 : 75) faktor-faktor yang mempengaruhi prestasi kerja:

a. Tingkat pendidikan

b. Keterampilan

c. Disiplin

d. Motivasi

e. Sikap dan etika kerja

f. Gizi dan kesehatan

g. Tingkat upah/penghasilan

h. Jaminan Sosial 


\title{
Jurnal Ecobisma Vol 5 No. 2 Juni 2018
}

\author{
i. $\quad$ Lingkungan dan iklim kerja \\ j. Sasaran produksi \\ k. Teknologi \\ 1. Hubungan perburuhan \\ m. Manajemen \\ n. Kesempatan berprestasi
}

\section{Pengertian Keselamatan dan kesehatan kerja}

Perhatian keamanan dan keselamatan kerja ini bertalian erat dengan perhatian kesehatan kerja (hygiene perusahaan). Keselamatan kerja adalah keselamatan yang bertalian dengan mesin, alat-alat kerja, lahan dan proses pengolahannya, landasan tempat bekerja dan lingkungan serta cara-cara melakukan pekerjaan. Agar definisi dari keselamatan kerja dapat dipahami secara jelas, terlebih dahulu diketahui mengenai kecelakaan kerja.

Menurut Benet dan Rumondang (2011 : 31) masalah kecelakaan ini sering terjadi di dalam perusahaan industri. Para ahli memberikan pengertian dari kecelakaan sebagai berikut : "Kecelakaan adalah setiap perbuatan atau kondisi tidak selamat yang dapat mengakibatkan kecelakaan". Sedangkan menurut Suma'mur (2012 : 12), adalah : "Kecelakaan adalah suatu kejadian yang tidak diharapkan, tidak terduga oleh karena di belakang peristiwa itu tidak terdapat unsur kesengajaan, lebih-lebih dalam bentuk perencanaan".

Menurut Sunyoto (2012 : 240), karyawan yang sehat jasmani dan rohani merupakan aset yang berharga. Untuk itu diperlukan berbagai macam fasilitas pendukung keselamatan dan kesehatan karyawan. Dalam menyediakan fasilitas keselamatan dan kesehatan karyawan dengan baik, ada tiga pokok yang menjadi penyebab terjadinya kecelakaan yaitu : peristiwa-peristiwa secara kebetulan, kondisi-kondisi dan tindakan-tindakan serta perbuatan-perbuatan yang membahayakan.

Menurut Mangkunegara (2013 : 161), istilah keselamatan mencakup kedua istilah risiko keselamatan dan risiko kesehatan. Keselamatan kerja menunjukkan kondisi yang aman atau selamat dari penderitaan, kerusakan atau kerugian di tempat kerja. Risiko keselamatan merupakan aspek-aspek dari lingkungan kerja yang dapat menyebabkan kebakaran, ketakutan aliran listrik, terpotong atau luka memar, keseleo, patah tulang, kerugian alat tubuh, penglihatan dan pendengaran. Sedangkan kesehatan kerja menunjukkan pada kondisi yang bebas dari gangguan fisik, mental, emosi atau rasa sakit yang disebabkan oleh lingkungan kerja. Risiko kesehatan merupakan faktor-faktor dalam lingkungan kerja yang bekerja melebihi periode waktu yang ditentukan, lingkungan yang dapat membuat stress emosi atau gangguan fisik.

Dalam penjelasan UU No. 14 Tahun 1969 tentang Ketentuan Pokok Mengenai Tenaga Kerja, Pasal 9 dan 10, disebutkan bahwa yang dimaksud dengan Hyperkes adalah: "Lapangan kesehatan yang ditujukan kepada pemeliharaan dan mempertinggi derajat kesehatan tenaga kerja, dilakukan dengan pemberian pengobatan, perawatan tenaga kerja sakit, mengatur tempat, cara-cara dan syarat-syarat yang memenuhi norma-norma hygiene perusahaan dan kesehatan kerja untuk mencegah penyakit baik sebagai akibat kerja maupun penyakit umum serta penetapan syarat-syarat kesehatan bagi perumahan tenaga kerja”. 
Faktor-Faktor yang Mempengaruhi Keselamatan dan Kesehatan Kerja

Keselamatan dan kesehatan kerja merupakan upaya supaya pekerja selamat di tempat kerjanya, sehingga terhindar dari kecelakaan termasuk upaya penyelamatan peralatan produksi.

Faktor keselamatan harus dijadikan pertimbangan utama dalam perencanaan peralatan dan perlengkapan. Lokasi pabrik harus mengindahkan perhitungan lingkungan agar masyarakat sekitarnya tidak sampai terganggu, bangunan pabrik harus dilengkapi dengan penerangan yang cukup, pengendalian kebisingan dan getaran, pengendalian suhu dan sarana.

Menurut Peraturan Menteri Tenaga Kerja dan Transmigrasi RI No. 02/Men/1980, faktor-faktor yang mempengaruhi keselamatan dan kesehatan kerja dapat di golongkan menjadi 4 faktor, yaitu:

a. Faktor Keterampilan

1) Pengetahuan

2) Pengalaman

b. Faktor Usaha

1) Usaha mental

2) Usaha fisik

c. Faktor Tanggung Jawab

1) Tanggung jawab pengawasan

2) Tanggung jawab terhadap peralatan

3) Tanggung jawab keselamatan orang lain

d. Faktor Keselamatan dan kesehatan kerja

1) Resiko kecelakaan

2) Kondisi kerja.

Hubungan Antara Keselamatan dan Kesehatan Kerja dengan Prestasi Kerja Karyawan

Menurut Mangkunegara (2013 : 161), istilah keselamatan mencakup kedua istilah risiko keselamatan dan risiko kesehatan. Keselamatan kerja menunjukkan kondisi yang aman atau selamat dari penderitaan, kerusakan atau kerugian di tempat kerja. Risiko keselamatan merupakan aspek-aspek dari lingkungan kerja yang dapat menyebabkan kebakaran, ketakutan aliran listrik, terpotong atau luka memar, keseleo, patah tulang, kerugian alat tubuh, penglihatan dan pendengaran. Sedangkan kesehatan kerja menunjukkan pada kondisi yang bebas dari gangguan fisik, mental, emosi atau rasa sakit yang disebabkan oleh lingkungan kerja. Risiko kesehatan merupakan faktor-faktor dalam lingkungan kerja yang bekerja melebihi periode waktu yang ditentukan, lingkungan yang dapat membuat stress emosi atau gangguan fisik.

Jadi, dapat dikatakan bahwa ada hubungan antara keselamatan dan kesehatan kerja dengan prestasi kerja, hal ini didukung oleh Paramita (2012), yang menyatakan bahwa keselamatan kerja dan kesejahteraan (K3) berpengaruh signifikan terhadap kinerja karyawan yang dimediasi oleh variabel motivasi kerja.

\section{METODE PENELITIAN}




\section{Jurnal Ecobisma Vol 5 No. 2 Juni 2018}

\section{Jenis Penelitian}

Penelitian ini menggunakan jenis penelitian asosiatif. Penelitian asosiatif merupakan penelitian yang bertujuan untuk mengetahui pengaruh ataupun juga hubungan antara dua variabel atau lebih. Penelitian ini mempunyai tingkatan tertinggi dibandingkan dengan diskriptif dan komparatif karena dengan penelitian ini dapat dibangun suatu teori yang dapat berfungsi untuk menjelaskan, meramalkan dan mengontrol suatu gejala (Sugiyono, 2007 : 11).

\section{Tehnik Pengumpulan Data}

Untuk memperoleh data serta informasi yang dibutuhkan, digunakan teknik pengumpulan data yaitu angket (Quesioner) yaitu dengan membagikan daftar pertanyaan yang berisi pertanyaan - pertanyaan tertutup untuk masingmasing variabel.

\section{Teknik Analisis Data Penelitian}

\section{Uji Kualitas Data}

a. Uji Validitas

Uji validitas digunakan untuk mengetahui sah atau valid tidaknya suatu kuesioner. Suatu kuesioner dikatakan valid jika pertanyaan pada kuesioner mampu untuk mengungkapkan peningkatan prestasi kerja. Uji validitas dilakukan dengan membandingkan nilai $r$ hitung (correlated item-total correlations) dengan nilai $r$ tabel. Jika nilai $r$ hitung $>r$ tabel dan bernilai positif maka pertanyaan tersebut dikatakan valid (Ghozali, 2006:49).

b. Uji Reliabilitas

Reliabilitas adalah alat untuk mengukur suatu kuesioner yang merupakan indikator dari variabel atau konstruk. Suatu kuesioner dikatakan reliabel atau handal jika jawaban seseorang terhadap pertanyaan adalah konsisten atau stabil dari waktu ke waktu. SPSS memberikan fasilitas untuk mengukur reliabilitas dengan uji statistik Cronbach Alpha $(\alpha)$. Suatu variabel dikatakan reliabel jika memberikan nilai $(\alpha)$ 0,60 (Ghozali, 2006:45).

\section{Analisis Regresi Sederhana}

Untuk mengetahui pengaruh atau hubungan variabel bebas (keselamatan dan kesehatan kerja) dengan variabel terikat (prestasi kerja karyawan), maka akan digunakan metode regresi linier sederhana dan analisis data juga menggunakan SPSS, rumusnya adalah sebagai berikut :

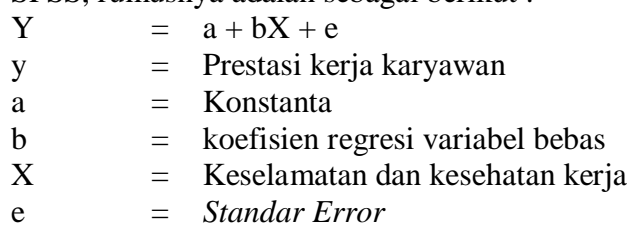

\section{Uji Asumsi Klasik}

\section{a. Uji Normalitas}

Menurut Ghozalli (2006), uji normalitas bertujuan untuk menguji apakah dalam model regresi variabel independen dan dependen memiliki distribusi normal atau tidak. Nilai residual mengikuti distribusi normal. Untuk melihat 
distribusi data normal atau tidak menggunakan analisa statistik, sebab Uji normalitas dengan grafik dapat menyesatkan kalau tidak hati-hati secara visual.

b. Uji Multikolinearitas

Menurut Ghozalli (2006), uji multikolinearitas bertujuan untuk menguji apakah model regresi ditemukan adanya korelasi antar variabel bebas (independen). Sebuah persamaan regresi dikatakan baik bila persamaan tersebut memiliki variabel independen yang saling tidak berkorelasi. Multikolinearitas dapat dilihat dari nilai tolerance variance inflation faktor (VIF) apabila nilai tolerance lebih besar dari 0,1 dan VIF kurang dari 10 angka maka dapat disimpulkan tidak tejadi gejala multikolinearitas.

c. Uji Heteroskedastisitas

Menurut Ghozalli (2006), uji heteroskedastisitas bertujuan untuk menguji apakah dalam model regresi terjadi ketidaksamaan varian dan residual pada suatu pengamatan kepengamatan yang lain. Model regresi yang baik adalah yang homoskesdatisitas atau tidak menjadi heteroskedastisitas.

\section{Uji Hipotesis}

a.

Koefisien Determinan $\left(\mathrm{R}_{2}\right)$

Koefisien determinan digunakan untuk mengukur besarnya pengaruh variabel bebas yang diteliti yaitu keselamatan dan kesehatan kerja (X), sedangkan variabel terikat adalah prestasi kerja karyawan $(\mathrm{Y})$. Koefisien determinant $\left(\mathrm{R}^{2}\right)$ berkisar antara nol sampai dengan satu $\left(0<\mathrm{R}^{2}<1\right)$. Hal ini berarti bila $\mathrm{R}^{2}=0$ menunjukkan tidak adanya pengaruh variabel bebas terhadap variabel terikat dan bila $\mathrm{R}^{2}$ mendekati 1 menunjukkan semakin kuatnya pengaruh variabel bebas terhadap variabel terikat.

b. Uji-t

Dilakukan untuk menguji setiap variabel bebas apakah ada pengaruh positif atau signifikan terhadap variabel terikat. Nilai uji t statistik akan dibandingkan dengan nilai t tabel dengan tingkat kesalahan $\alpha=5 \%$.

HASIL DAN PEMBAHASAN

Uji Kualitas Data

Uji Validitas Data

Tabel 2.

Hasil Uji Validitas Y (Prestasi kerja karyawan)

\begin{tabular}{|c|c|c|c|}
\hline Pernyataan & $\mathrm{r}_{\text {hitung }}$ & $\mathrm{r}_{\text {tabel }}$ & Validitas \\
\hline Butir 1 & 0.704 & 0.235 & Valid \\
\hline Butir 2 & 0.543 & 0.235 & Valid \\
\hline Butir 3 & 0.638 & 0.235 & Valid \\
\hline Butir 4 & 0.674 & 0.235 & Valid \\
\hline
\end{tabular}

Sumber: Hasil Pengolahan SPSS 16.0, 2016.

Tabel di atas menunjukkan bahwa seluruh butir pernyataan telah valid karena $r_{\text {hitung }}>r_{\text {tabel}}$. Dengan demikian, kuisioner dapat dilanjutkan pada tahap pengujian reliabilitas.

Tabel 3.

Hasil Uji Validitas Variabel X (Keselamatan dan Kesehatan Kerja (K3)) 


\section{Jurnal Ecobisma Vol 5 No. 2 Juni 2018}

\begin{tabular}{|c|c|c|c|}
\hline Pernyataan & $\mathrm{r}_{\text {hitung }}$ & $\mathrm{r}_{\text {tabel }}$ & Validitas \\
\hline Butir 1 & 0.729 & 0.235 & Valid \\
\hline Butir 2 & 0.747 & 0.235 & Valid \\
\hline Butir 3 & 0.713 & 0.235 & Valid \\
\hline Butir 4 & 0.524 & 0.235 & Valid \\
\hline Butir 5 & 0.705 & 0.235 & Valid \\
\hline
\end{tabular}

Sumber: Hasil Pengolahan SPSS 16.0, 2016.

Tabel di atas menunjukkan bahwa seluruh butir pernyataan telah valid karena $r_{\text {hitung }}>r_{\text {tabel. }}$. Dengan demikian, kuisioner dapat dilanjutkan pada tahap pengujian reliabilitas.

\section{Uji Reliabilitas}

Tabel 4.

Hasil Uji Reliabilitas Variabel

\begin{tabular}{|l|c|c|c|}
\hline \multicolumn{1}{|c|}{ Variabel } & $\begin{array}{c}\text { Jumlah } \\
\text { Pertanyaan }\end{array}$ & $\begin{array}{c}\text { Cronbach's } \\
\text { Alpha }\end{array}$ & Keterangan \\
\hline Prestasi kerja karyawan (Y) & 4 & 0.817 & Reliable \\
\hline Keselamatan dan kesehatan kerja (K3) & 5 & 0.858 & Reliable \\
\hline
\end{tabular}

Sumber: Hasil Pengolahan SPSS 16.0, 2016.

Pada pengujian realibilitas nilai Cronbach's Alpha harus lebih besar dari 0,60 maka instrumen penelitian dapat dikatakan reliabel. Dari tabel di atas dapat dilihat bahwa nilai Cronbach's Alpha > 0,6 berarti bahwa instrumen tersebut reliabel.

\section{Pengujian Asumsi Klasik}

\section{Pengujian Normalitas Data}

Normal P.P Plot of Regression Standardized Residual

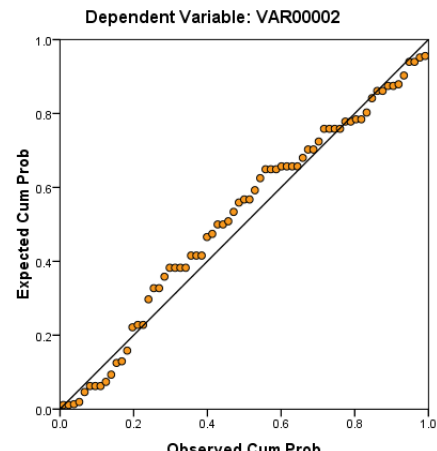

Sumber: Hasil pengolahan data primer (kuesioner) dengan SPSS 16.0

Gambar 1. Grafik P-P Plot

Dari gambar grafik di atas, dapat diketahui bahwa titik-titik menyebar sekitar garis dan mengikuti garis diagonal maka nilai residual telah normal.

\section{Pengujian Multikolinearitas}


Jurnal Ecobisma Vol 5 No. 2 Juni 2018

Tabel 5.

Hasil Uji Multikolinearitas

\begin{tabular}{|c|c|c|c|}
\hline \multicolumn{2}{|c|}{ Model } & \multicolumn{2}{c|}{ Collinearity Statistics } \\
\cline { 3 - 4 } & Tolerance & VIF \\
\hline 1 & Keselamatan dan kesehatan kerja (K3) & 1.000 & 1.000 \\
\hline
\end{tabular}

a. Dependent Variable : prestasi kerja karyawan

Sumber: Hasil pengolahan data primer (kuesioner) dengan SPSS.

a. Nilai VIF dari nilai keselamatan dan kesehatan kerja (K3) lebih kecil atau dibawah 5 (VIF < 5), ini berarti tidak terkena multikolinearitas antara variabel independen dalam model regresi.

b. Nilai Tolerance dari nilai keselamatan dan kesehatan kerja (K3) lebih besar dari 0,1 ini berarti tidak terdapat multikolinearitas antar variabel independen dalam model regresi.

\section{Pengujian Heteroskedastisitas}

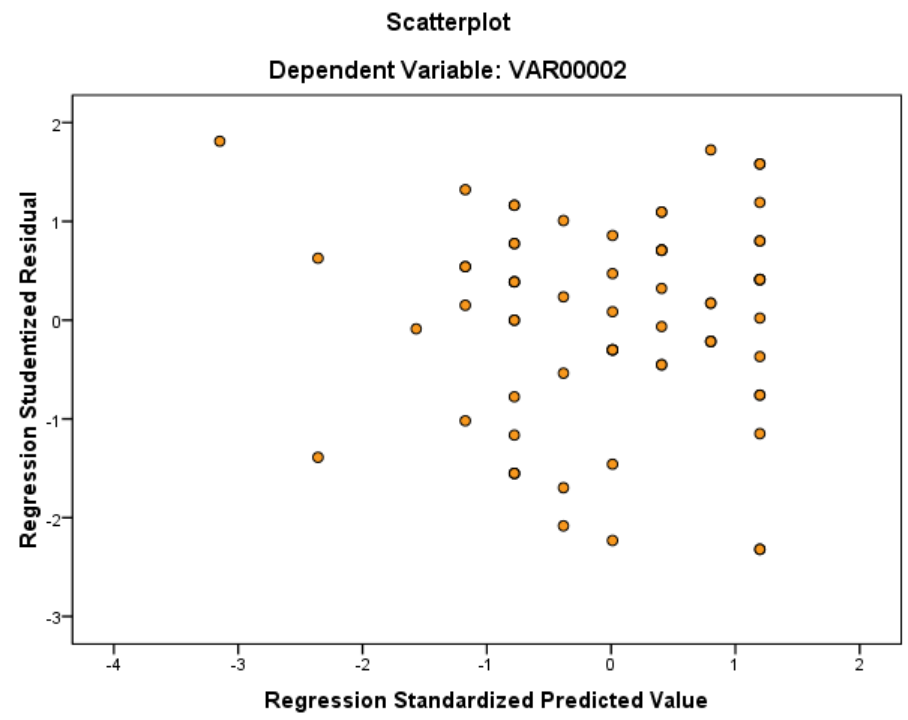

Sumber: Hasil pengolahan data primer (kuesioner) dengan SPSS (2016) Gambar 2. Heteroskedastisitas

Berdasarkan Gambar 2 dapat terlihat bahwa tdak ada pola yang jelas, serta titik-titik menyebar di atas dan di bawah angka 0 pada sumbu Y, maka berdasarkan metode grafik tidak terjadi heteroskedastisitas pada model regresi.

\section{Uji Hipotesis}

Koefisien Determinant

Tabel 6.

Model Summary 
Jurnal Ecobisma Vol 5 No. 2 Juni 2018

\begin{tabular}{|c|c|c|c|c|}
\hline Model & $\mathrm{R}$ & $\mathrm{R}$ Square & $\begin{array}{c}\text { Adjusted R } \\
\text { Square }\end{array}$ & $\begin{array}{c}\text { Std. Error of } \\
\text { the Estimate }\end{array}$ \\
\hline 1 & .355 & .126 & .113 & .260985 \\
\hline
\end{tabular}

Sumber : Data Primer Diolah, 2016.

Dari tabel diatas, diperoleh Adjusted R Square untuk Y sebesar 0,113. Hal ini berarti 11,3\% variabel prestasi kerja karyawan (Y) mampu dijelaskan oleh variabel $\mathrm{X}$ (keselamatan dan kesehatan kerja (K3)) dan sisanya sebesar 88,7 \% ditentukan oleh variabel lain di luar variabel penelitian ini.

Uji t

Tabel 7.

Hasil Uji t

\begin{tabular}{|l|r|r|r|r|r|}
\hline \multirow{2}{*}{ Model } & \multicolumn{2}{|c|}{$\begin{array}{c}\text { Unstandardized } \\
\text { Coefisients }\end{array}$} & $\begin{array}{c}\text { Standardized } \\
\text { Coefisients }\end{array}$ & \multirow{2}{*}{$\mathrm{t}$} & \multirow{2}{*}{ Sig } \\
\cline { 2 - 4 } & \multicolumn{1}{|c|}{ B } & \multicolumn{1}{c|}{ Std. Error } & \multicolumn{1}{c|}{ Beta } & & \\
\hline (Constant) & 6.224 & 2.764 & & 2.251 & .028 \\
Keselamatan dan & .389 & .125 & .355 & 3.111 & .003 \\
Kesehatan Kerja (K3) & & & & & \\
\hline
\end{tabular}

Sumber : Data Primer Diolah, 2016.

Nilai t-hitung untuk $X>t$-tabel $(3,111>1,996)$, maka keselamatan dan kesehatan kerja (K3) berpengaruh positif dan signifikan secara statistik terhadap prestasi kerja karyawan pada PT. Pertamina (Persero) Medan. Dengan demikian dapat dinyatakan bahwa hipotesis dalam penelitian ini dapat diterima.

\section{Pembahasan}

Perhatian keamanan dan keselamatan kerja ini bertalian erat dengan perhatian kesehatan kerja (hygiene perusahaan). Keselamatan kerja adalah keselamatan yang berkaitan dengan mesin, alat-alat kerja, lahan dan proses pengolahannya, landasan tempat bekerja dan lingkungan serta cara-cara melakukan pekerjaan. Agar definisi dari keselamatan kerja dapat dipahami secara jelas, terlebih dahulu diketahui mengenai kecelakaan kerja. Keselamatan dan kesehatan kerja merupakan upaya supaya pekerja selamat di tempat kerjanya, sehingga terhindar dari kecelakaan termasuk upaya penyelamatan peralatan produksi.

Faktor keselamatan harus dijadikan pertimbangan utama dalam perencanaan peralatan dan perlengkapan. Lokasi pabrik harus mengindahkan perhitungan lingkungan agar masyarakat sekitarnya tidak sampai terganggu, bangunan pabrik harus dilengkapi dengan penerangan yang cukup, pengendalian kebisingan dan getaran, pengendalian suhu dan sarana.

Menurut Mangkunegara (2013 : 161), istilah keselamatan mencakup kedua istilah risiko keselamatan dan risiko kesehatan. Keselamatan kerja menunjukkan kondisi yang aman atau selamat dari penderitaan, kerusakan atau kerugian di tempat kerja. Risiko keselamatan merupakan aspek-aspek dari lingkungan kerja yang dapat menyebabkan kebakaran, ketakutan aliran listrik, terpotong atau luka memar, keseleo, patah tulang, kerugian alat tubuh, penglihatan dan pendengaran. Sedangkan kesehatan kerja menunjukkan pada kondisi yang bebas dari gangguan fisik, mental, emosi atau rasa sakit yang disebabkan oleh lingkungan kerja. Risiko kesehatan merupakan faktor-faktor dalam lingkungan kerja yang bekerja melebihi 


\section{Jurnal Ecobisma Vol 5 No. 2 Juni 2018}

periode waktu yang ditentukan, lingkungan yang dapat membuat stress emosi atau gangguan fisik.

Dari hasil uji regresi dinyatakan bahwa keselamatan dan kesehatan kerja (K3) berpengaruh positif dan signifikan terhadap prestasi kerja karyawan pada PT. Pertamina (Persero) Medan. Hal ini sesuai dengan penelitian yang dilakukan oleh Hasanah, Iswatun (2014), dengan hasil penelitiannya menunjukkan bahwa keselamatan dan kesehatan kerja berpengaruh signifikan dan positif terhadap kinerja karyawan CV. Manunggal Jaya Boyolali. Berdasarkan hasil pengujian empiris variabel program keselamatan dan kesehatan kerja memiliki nilai koefisien sebesar 0.725 dengan nilai t hitung 4.923 serta nilai signifikansi 0.001 .

Dari penyebaran kuisioner yang peneliti lakukan dapat diketahui bahwa responden menyatakan perusahaan berupaya membuat kondisi kerja yang aman, perusahaan juga mengutamakan pendidikan dan pelatihan tentang keselamatan dan kesehatan kerja (K3) yang berarti perusahaan menganggap sangat penting karyawan bagi perusahaan. Begitu juga dengan adanya usaha perusahaan dalam memberikan standar pelayanan kesehatan sesuai dengan peraturan yang berlaku yang telah ditetapkan.

Dalam penjelasan UU No. 14 Tahun 1969 tentang Ketentuan Pokok Mengenai Tenaga Kerja, Pasal 9 dan 10, disebutkan bahwa yang dimaksud dengan Hyperkes adalah: "Lapangan kesehatan yang ditujukan kepada pemeliharaan dan mempertinggi derajat kesehatan tenaga kerja, dilakukan dengan pemberian pengobatan, perawatan tenaga kerja sakit, mengatur tempat, cara-cara dan syarat-syarat yang memenuhi norma-norma hygiene perusahaan dan kesehatan kerja untuk mencegah penyakit baik sebagai akibat kerja maupun penyakit umum serta penetapan syarat-syarat kesehatan bagi perumahan tenaga kerja”.

Prestasi kerja merupakan gabungan dari tiga faktor penting yaitu kemampuan dan minat seorang pekerja, kemampuan dan penerimaan atas penjelasan delegasi tugas, serta peran dan tingkat motivasi seorang pekerja. Semakin tinggi ketiga faktor di atas, semakin besar pula prestasi kerja karyawan. Menurut Hasibuan (2005: 94) prestasi kerja adalah hasil kerja yang dicapai seseorang dalam melaksanakan tugas tugas yang dibebankan kepadanya yang di dasarkan atas kecakapan, pengalaman, dan kesungguhan serta waktu. Prestasi kerja merupakan gabungan dari tiga faktor penting yaitu kemampuan dan minat seorang pekerja,kemampuan dan penerima atas penjelasan delegasi tugas, serta peran dan tingkat motivasi seorang pekerja. Semakin tinggi ketiga faktor di atas, semakin besarlah prestasi kerja karyawan bersangkutan.

Prestasi kerja sebagai hasil kerja (output) yang berasal dari adanya perilaku kerja serta lingkungan kerja tertentu yang kondusif. Dalam menentukan faktor penilaian individu pegawai, maka lingkungan kerja sebagai kesempatan untuk berprestasi yang dapat dipengaruhi oleh adanya peralatan kerja, bahan, lingkungan fiskal kerja, perilaku kerja pegawai yang lain, pola kepemimpinan, kebijakan organisasi, informasi serta penghasilan secara keseluruhan akan dianggap konstan karena bersifat pemberian, berasal dari luar diri pegawai dan bukan merupakan perilaku pegawai.

Jadi, dapat dikatakan bahwa ada hubungan antara keselamatan dan kesehatan kerja dengan prestasi kerja, hal ini didukung oleh Paramita (2012), yang
Commented [A2]: TAMBAHKAN KETERANGAN APAKAH HIPOTESIS ANDA PADA BAB II DITERIMA ATAU DITOLAK 


\section{Jurnal Ecobisma Vol 5 No. 2 Juni 2018}

menyatakan bahwa keselamatan kerja dan kesejahteraan (K3) berpengaruh signifikan terhadap kinerja karyawan yang dimediasi oleh variabel motivasi kerja.

\section{SIMPULAN DAN SARAN}

Simpulan

Kesimpulan dalam penelitian ini adalah :

1. Hasil analisis deskriptif menunjukkkan bahwa perusahaan mengganggap sangat penting untuk kesehatan dan keselamatan kerja (K3) bagi karyawan perusahaan.

2. Bahwa variabel keselamatan dan kesehatan kerja (K3) berpengaruh positif dan signifikan terhadap prestasi kerja karyawan pada PT. Pertamina (Persero) Medan.

\section{Saran}

Saran dalam penelitian ini adalah :

1. Keselamatan dan kesehatan kerja (K3) di dalam perusahaan harus ditingkatkan, salah satu caranya adalah perusahaan harus senantiasa menyediakan alat pelindung diri sehingga dapat melindungi karyawan dan mencegah kejadian yang tidak diinginkan.

2. Untuk meningkatkan prestasi kerja karyawan SPBU sebaiknya pihak manajemen lebih memperhatikan aspek peraturan dan prosedur K3 karena dari hasil penelitian pengaruh terkecil diperoleh dalam keselamatan dan kesehatan kerja (K3).

3. Kemudian bagian keselamatan dan kesehatan kerja (K3) harus secara berkala memberikan pelatihan dan pendidikan mengenai sistem prosedur kerja, audit keselamatan, pemakaian alat pelindung diri, sistem inspeksi dan pemeliharaan peralatan. Hal ini yang paling penting ialah menciptakan kesadaran yang tinggi kepada semua karyawan terhadap pentingnya keselamatan dan kesehatan kerja.

\section{DAFTAR PUSTAKA}

Bennet dan Silalahi, Rumondang, 2011, Manajemen Kesehatan dan Keselamatan Kerja Seri Manajemen, PT. Pustaka Binawan Presindo, Jakarta.

Ghozali, Imam. 2006. Aplikasi Analitis Multiwarlate Dengan Program SPSS, Edisi Ketiga, BP-Universitas Diponegoro, Semarang.

Gomes, Faustino Cardoso, 2003, Manajemen Sumber Daya Manusia, Andi Offset, Yogyakarta.

Hasanah, Iswatun, 2014, Pengaruh Keselamatan dan Kesehatan Kerja terhadap Kinerja Karyawan CV Manunggal Jaya di Boyolali

Hasibuan, Malayu SP, 2005, Manajemen Sumber Daya Manusia, Edisi Revisi, Penerbit Ghalia Indonesia, Jakarta.

Heidjarachman, Ranupandjojo, 2011, Manajemen Sumber Daya Manusia, Cetakan Kedua, BPFE - Yogyakarta. 


\section{Jurnal Ecobisma Vol 5 No. 2 Juni 2018}

Mangkunegara, A.A. Anwar Prabu. 2013. Manajemen Sumber Daya Manusia Perusahaan, Remaja Rosdakarya, Bandung.

Panggabean, S. Mutiara, 2002. Manajemen Sumber Daya Manusia, Ghalia Indonesia, Jakarta.

Paramita, Catarina Cori Pradnya, 2012, Pengaruh Keselamatan Dan Kesehatan Kerja Terhadap Prestasi Kerja Karyawan Pada PT. PLN (Persero) APJ Semarang

Peraturan Menteri Tenaga Kerja dan Transmigrasi Republik Indonesia No.02/Men/1980, Tentang Pemerikasaan Kesehatan Tenaga Kerja Dalam Menyelenggarakan Kesehatan Kerja.

Ruky, S. Achmad, 2002. Sistem Manajemen Kinerja, PT. Gramedia Pustaka Utama, Jakarta.

Simamora, Henry. 2006. Manajemen Pemasaran Internasional, Jilid I, Edisi Kedua. Jakarta: Rineka Cipta.

Suma'mur PK, 2012, Hygiene Perusahaan dan Keselamatan Kerja, Cetakan VII, Gunung Agung, Jakarta.

Sunyoto, Danang. 2012. Teori, Kuesioner, dan Proses Analisis Data Perilaku Organisasional Cetakan Pertama. Yogyakarta: CAPS.

Sutrisno Hadi, 2008, Statistik Jilid II, Liberty : Yogyakarta.

Tsenawatme, Aleks, 2012, Pengaruh Keselamatan Dan Kesehatan Kerja Terhadap Kinerja Karyawan (Studi Pada Departemen Social Outreach \& Local Development (SLD) dan Community Relations (CR) PT.Freeport Indonesia.

Umar Husein, 2007, Riset Pemasaran \& Prilaku Konsumen, Gramedia Pustaka Utama dan JBRC, Jakarta.

Undang-Undang Republik Indonesia No. 14 Tahun 1969 tentang Ketentuan Pokok Mengenai Tenaga Kerja, Pasal 9 dan 10.

William, Richard. 2003. Human Resources Management (Terjemahan Wungu), Salemba Empat, Jakarta

Wungu, 2003. Human Resources Management, Salemba Empat, Jakarta 